\title{
Texting to Motivate Language Learning: WhatsApp Group Chats and Near Peer Role Modeling (NPRM)
}

\author{
Aliya Gimranova, Madina Nurmanova, and A. S. CohenMiller
}

\begin{abstract}
During the Soviet era, the Kazakh language underwent harsh times and was on the brink of extinction from urban areas in Kazakhstan. Today, the country is paving its way towards reviving the language. This article details an effort to support Kazakh language learning in motivating secondary school students through the use of technology. Through the development of a small-scale project connecting university students as Near Peer Role Models (NPRM) with secondary school students, we used WhatsApp texting group chats as a means to encourage authentic communication in the Kazakh language and discovered five tangible results and suggested next steps.
\end{abstract}

\section{Background}

We (the first two authors) are graduate students living and working in Astana, Kazakhstan. In this article, we detail how we used digital technology to enhance and motivate language learning for secondary school students to learn Kazakh. As part of a practice-based graduate course and larger pilot project, we used Near Peer Role Modeling (NPRM) to create discussions with WhatsApp texting groups between seventh and eighth graders learning Kazakh (one of the official languages of Kazakhstan) and university student volunteer "near peers." In using NPRM, which assumes people are naturally inclined to replicate behaviors/attitudes of those close in age/interests, we found students enjoyed learning Kazakh during the project and showed motivation for continued interaction with their "near peer" university student volunteers.

\section{The Kazakhstani Context}

The country has the ninth largest territory in the world and borders with Russia, China, Kyrgyzstan, Uzbekistan, and Turkmenistan. Having gained independence in 1991 from the Soviet Union, the official language of the country is Kazakh, yet Russian is the language used for interethnic communication ("The Republic of Kazakhstan," n.d.). Despite the fact that the Kazakh language is the official language, and therefore the language of public administration, legislation, legal proceedings, and documentation management, there is an acute problem of Kazakh language acquisition among the population (Belova, 2013). As teachers ourselves, we have seen firsthand the lack of fluency in Kazakh for many students, in particular those born in our expanding digital era. Kazakhstan is a country with 25 years of independence and more than 130 nationalities. In an endeavor to shed its Soviet past and Russian-dominated interethnic communication, the country is attempting to pave its way towards 
reviving the language that is the mother tongue of the titular Kazakh nation. The government has granted Kazakh the status of a government language and Russian the status of official language. The significance of knowing Kazakh has been articulated in government programs and is mandatory in all governmental organizations. Additionally, the Kazakh language is promoted by the government due to "sentimental" reasons (Matuszkiewicz, 2010, p. 219), as both older and younger generations are concerned about their mother tongue being superseded by other languages.

\section{Learning Kazakh}

The emphasis on Kazakh language acquisition is not only a policy to promote the state language, but also considered as the most significant step for Kazakhs towards not losing the culture and the spirit of belonging. As a Kazakh language teacher explained, "Now we know more things about the whole world, about the history of every country, about geography ... but we've lost something about the culture, about the language today" (Witte, 2014, para. 8). The Kazakh people fear losing their roots and their national identity that tie them strongly to the knowledge of their mother tongue. During the Soviet era, the Kazakh language underwent harsh times during the Soviet era and was on the brink of extinction from urban areas in Kazakhstan. In the late 1980s, only $11.3 \%$ of all urban schools had the Kazakh language as a medium of instruction (Fierman, 2006). Even though there have been numerous policies and attempts by the government to revive the language and expand its use across all areas before the state gained sovereignty, "Kazakh's functions continue to be limited to the household and traditional culture" (Abdyeva, Nogaybaeva, Togzhanova, \& Shynybaeva, 2015).

To address this problem, one approach has been to implement the Kazakh language as a separate subject in all schools across the country. Additional approaches include governmental reforms and policies that aim to have 95\% of all citizens speaking Kazakh by 2025 (Zhoyamergenkyzy, 2013). For instance, a major reform will be implemented in September 2019, where Kazakhstan plans to introduce a trilingual education policy, which is intended to contribute to the development of the Kazakh language along with English and Russian. As of September 1, 2017, the policy of teaching Kazakh as a subject has been complemented with a focus on integrating Kazakh within other lessons, with the goal of having all school graduates become fluent in Kazakh by 2020 (Kasenova, 2016). While some schools teach primarily in Russian, others teach primarily in Kazakh—these schools are referred to as Russian medium or Kazakh medium schools. In the Kazakh medium schools, courses such as Mathematics, Kazakh language, Kazakh literature, History of Kazakhstan, Geography, and a number of other subjects will be taught in Kazakh. Although it is beyond the scope of this article to discuss the consequences of introducing a trilingual education policy, there is a considerable amount of concern about the practical complexities of sustaining acquisition of all three languages by native and nonnative speakers due to existing issues in education-funding of education, quality of teaching staff, shortage of quality textbooks in the Kazakh language, the state of rural schools, and so forth.

According to Arenov and Kalmykov (1997), the Kazakh language is preferred for communication at home by the ethnically Kazakh population, but the language of interethnic communication, business, 
and technology continues to be Russian. Nowadays, the influence of the English language has become even stronger than Russian in all areas of life, particularly education.

\section{Facilitating Language Support: A Needs-Based Assessment}

Within our graduate course, we were to locate a project to implement in order to support the development of the school. The topic was to be determined by those within the school and not suggested by us. The school where the project was to be implemented is a well-equipped school that has achieved high standards in teaching and learning. It has been accredited by international schools and has implemented the International Baccalaureate accreditation. Because of these high achievements, we found it initially challenging to locate a project to improve the school as most aspects had already been addressed.

Yet, with the use of a needs assessment informed by the classic work of Stephen Steadham (1980), we learned how teachers wanted help to increase students' motivation for learning Kazakh. The assessment included talking to the school's representatives, the lead instructors for the language departments, and the pertinent teachers.

Following the suggestions and recommendations made by our faculty supervisor (third author), we spent time observing language lessons and talked to the Kazakh language teachers who elaborated on what hindered learners' language acquisition, which was crucial in establishing that the learners are unmotivated with regard to the Kazakh language. We learned that those who struggled the most in Kazakh were the seventh and eighth graders. This knowledge led us to phase two of a three-phase plan for assessing needs, which included analyzing the students' needs and ways to address them, and also, measuring our own capabilities and matching them to the project's timeframe. After synthesizing the gathered data from teachers about students' needs and interests, we started to plan our project implementation.

As teachers ourselves, we have seen the challenges faced by many students in learning an additional language. For many students, while they may have grown up hearing Kazakh in their home or in the community, it is often their second or third language. During the analysis of this problem, we learned that students' struggle with learning Kazakh appeared to not be a result of teaching methodology or curriculum, but related to the motivation to learn Kazakh. It was suggested that seventh and eighth graders appeared to lack motivation related to potential aspects such as little encouragement or resources at home to learn Kazakh, lack of up-to-date, interactive, and adapted resources, and/or a result of a global trend to use English in all areas of their lives.

These potential obstacles for learning Kazakh are discussed in an article by Fierman (2006), who asserts that many parents choose schools with Russian-medium instruction (instead of Kazakh) because the quality of instruction is considered better. While there are challenges to learning Kazakh in secondary school, there also challenges within higher education institutions where there may be a shortage of textbooks for subjects in Kazakh. This has resulted in Kazakh groups using textbooks written in Russian 
for their studies at universities and colleges. Furthermore, there is a teacher shortage, especially in urban areas as often teacher salaries are relatively low in comparison with other professions. Also, as state funding for education is moderate, new interactive and up-to-date resources are hard to find in the Kazakh language (Fierman, 2006). These factors contribute to creating tension within the community between pursuing personal goals of high-quality education (which is often offered in Russian) and also sustaining a sense of national identity represented by knowledge of the Kazakh language.

Recognizing Kazakh language learning as a struggle for many students and teachers, we implemented a small-scale project incorporating digital technology through the use of texting as one of the primary activities to help motivate students to learn Kazakh within the urban secondary school for gifted learners. The project's goal was to motivate seventh and eighth graders to learn the Kazakh language, which while their mother tongue, has historically and geographically been superseded by other languages, in particular Russian. All seventh graders and one small group of eighth graders were identified as students having the lowest Kazakh language level according to the school's language acquisition framework.

\section{Student Motivation and Near Peer Role Models: A Conceptual Framework}

In order to explore various opportunities for motivating learners, we consulted experts in relevant educational fields: Kazakh language experts from two affiliated organizations; our course faculty; seventh and eighth grade teachers at the school; and a teacher from the university's Kazakh language department. Based on the results of these discussions and a related literature review, we found that defining and understanding how to address student motivation was difficult. As Dornyei (2014) notes, although the term "motivation" is used frequently, often, "the meaning of the concept can span such a wide spectrum that sometimes we wonder whether people are talking about the same thing at all" (p. 518). Ultimately, we found an explanation by Dornyei (2014) and Gardner and Maclntyre (1991) to be useful for our framing of student motivation. Dornyei (2014) explains Gardner and MacIntyre's social psychological approach to motivation, which describes "integrative motivation" (as cited in Dornyei, 2014, p. 520) as a feeling of wanting to be a part of a community of speakers. Explaining Gardner and Maclntyre's concept of integrative motivation, Dornyei notes that positive feelings and attitudes towards the speakers and culture of a foreign language can enhance learners' interest to acquire integrative motivation in order to become closer or similar to the community of foreign language speakers.

Similarly, the Near Peer Role Model theory explains that people are naturally inclined to replicate behaviors and attitudes of those who are closer to us in terms of age and interests, that is, learners would more likely act like their peers or those who are a few years older than themselves, if they have a feeling of acknowledgment and respect for them (Murphey, 1998). Explaining the notion of generative learning and peer learning, Murphey explains, 
Perhaps even more valuable is knowing how to create generative learning structures that allow for quality interaction in which learners can learn from and inspire each other. Structuring classroom experiences to enhance near peer role modeling may be one of the most powerful ways teachers can enhance learning. (p. 4)

From this framework, we saw a potential way to support and increase interest in the Kazakh language by involving role models in creating classroom experiences that exist both within the formal classroom and beyond it, through the use of common digital tools that feel authentic for language learning (Gilmore, 2007)—specifically texting. Through using texting and discussions between students and near peers, language learning was introduced in a "stealth" manner (CohenMiller, 2008), within a typical conversation.

As motivation is a dynamic concept with many factors (Dornyei, 2001), we chose not to measure motivation, but to examine how NPRM can find practical applications with seventh and eighth grade language learners who struggled with motivation. We hoped to provide external assistance to teachers in motivating learners and drew from the work of Murphey (1998) and Ruddick and Nadasdy (2013), in which the researchers demonstrated that NPRM could have a positive impact on learners in a language classroom. Having been informed by the Dornyei's (2014) explanation of motivation and the NPRM concept (Murphey, 1998), we developed a framework for our project plan and implementation. This article focuses on one aspect of that project, learning with technology, in particular using WhatsApp texting groups to increase motivation.

\section{Aiming to Increase Motivation Through Digital Technology and Near Peer Role Models}

While the overall project was both to motivate language learning and assist in achieving learning objectives within the classroom, the aims of using Whatapp chat groups within the school context centred primarily on motivating Kazakh language learners in the seventh and eighth grades. The tasks of the project included improving learners' speaking skills, enriching learners' vocabulary, and lowering the language barrier-affective filter (the psychological and emotional state of the learner which may hinder acquisition of the language)—-that learners might have while speaking Kazakh.

We recognized that participants involved in the pilot project were going to be essential to its success. According to the NOOA DEP Manual (2009), "In the long run, project sustainability will depend on the degree to which participants benefit directly, short-term and long-term, from the experiences or services" (p. 45). Therefore, finding appropriate peer role models was quite important. A first step involved locating near peer role models for seventh and eighth grade Kazakh language learners. As we knew of a local club at our university that centres on learning Kazakh, we approached them with our idea. After meeting with the club's president and its six representatives and presenting the concept of our project, we obtained approval for students to take part in the Near Peer Role Model implementation. The volunteers were mostly first- and second-year undergraduate students from different departments 
across the university. They seemed to be very excited about this project, because it was the first time they were going to work with schoolchildren and volunteer in an external organization.

Planning the implementation of the project was challenging because of both the time limits and because we relied on resources out of our control-university volunteer club members. We had several meetings with local school teachers and volunteer undergraduate students, and constantly collaborated on appropriate dates and time ranges, because both local school students and university volunteers were extremely busy and had little time for extra activities. As a result, we managed to arrange a timeframe for three activities aimed at enhancing the motivation of the targeted learners.

We participated in the activities along with undergraduate volunteers and received assistance from Kazakh teachers at the local school. Before planning the activities, we used a basic sign-up sheet to define the common aim and how to document the progress and responsibility of all those involved.

Kazakh language teachers selected students who needed additional support in language learning. In total, 76 learners were selected with 65 students from the seventh grade and 11 students from the eighth grade. We sent a consent form and received parental consent for the students to be involved in the project prior to its implementation. Once we received consent, we arranged a meeting with the students. During this meeting, we presented our ideas and the steps involved in the activities. We shared the schedule of the activities, which would all be conducted in their Kazakh language classes with no need for extra homework or any other demands made on the students (see Table 1).

\begin{tabular}{|c|c|c|c|c|}
\hline \multicolumn{5}{|c|}{$\begin{array}{l}\text { Table } 1 \\
\text { Details of project activities }\end{array}$} \\
\hline \multicolumn{5}{|c|}{\begin{tabular}{l|l} 
& Aims
\end{tabular}} \\
\hline $\begin{array}{l}\text { Communicative } \\
\text { session via } \\
\text { WhatsApp } \\
\text { application }\end{array}$ & $\begin{array}{l}\text { To organize an informal } \\
\text { communication platform } \\
\text { between learners and } \\
\text { university volunteer } \\
\text { students on various topics } \\
\text { of interest for teenagers in } \\
\text { order to improve learners' } \\
\text { communicative writing } \\
\text { and speaking skills in } \\
\text { Kazakh and to enrich their } \\
\text { vocabulary domain. } \\
\text { To raise learners' } \\
\text { motivation. }\end{array}$ & $\begin{array}{l}\text { April 12, } 2017 \\
\text { 7th grade groups } 1 \text { and 2: } \\
\text { 8:15 am - 9:15 am } \\
\text { (2 groups in parallel) } \\
\text { 8th grade group 1: } \\
\text { 11:30 am -12:30 pm } \\
\text { (1 group) } \\
\text { 7th grade groups } 3 \text { and 4: } \\
\text { 13:40 pm - 14:40 pm } \\
\text { (2 groups in parallel) } \\
7 \text { th grade groups } 5 \text { and 6: } \\
\text { 14:45 pm - } 15: 45 \text { pm } \\
\text { (2 groups in parallel) } \\
\text { Duration: } 1 \text { hour for each } \\
\text { class }\end{array}$ & $\begin{array}{l}\text { Project managers, } \\
\text { university volunteer } \\
\text { undergraduate } \\
\text { students }\end{array}$ & $\begin{array}{l}\text { Smartphones, } \\
\text { Internet }\end{array}$ \\
\hline
\end{tabular}


In developing a detailed timeline, we were able to not add excessive additional work to the students' schedule, and instead incorporated it within their regular lives. This point was particularly important, as these students were especially busy with their coursework already and we did not want to add any further commitments that might deter them from wanting to learn more.

\section{Communicative Sessions With WhatsApp Texting Groups}

While we used three activities throughout the project implementation, this article discusses the use of the first one-digital technology with near peer role models referred to as Communicative Session via WhatsApp (other activities included an interactive oral discussion sessions in the classroom and the development of an academic Monopoly-style game, but are beyond the scope of this article). In contrast to other texting applications such as iMessage, WhatsApp has a feature that facilitates directly replying to individual texts within the group texting through nested replies. While we could have used other mobile phone text and messaging applications such as Facebook Messenger, Skype, Viber, WeChat, of which many have group chats features, we chose WhatsApp both because it is the most popular messaging app in Kazakhstan and has the additional feature that allows for nested direct replies. The common use of the application can be seen as all students had the app already installed and some students mentioned that the first app they opened in the morning was WhatsApp. Group messaging can typically become "messy" in that many topics can overlap, making it challenging to respond to a question or comment to an individual's comment clearly. WhatsApp's nested feature replies allow for a cleaner thread of responses within a group message chat, supporting clearer responses to individual questions or comments.

The idea of this activity was generated after brainstorming during a consultation with Kazakh language teachers in the school. The initial goal was to use the communication medium, focusing on the use of technology which the participants were commonly using, between the targeted students and university volunteers. We considered multiple forms, such as e-mail, forum, social media, or a common chatroom. By eliminating other options due to their potential flaws (for example, e-mail would be too personal and it is time-consuming to reach out to every secondary school student), we determined that WhatsApp was the best option as it allows creating one common chat in an app that the students use regularly; it allows sending and receiving instant messages both in group and individual format, and allows messages to be read quickly (i.e., the built-in notifications integrated with students' phones).

Additionally, there were technical advantages in using a WhatsApp discussion-simple operation, low cost, availability, and immediacy. There was also a strong educational advantage that we hoped to develop, described by Bouhnik and Deshen (2014) as, "the creation of a pleasant environment and an in-depth acquaintance with fellow students, which had a positive influence upon the manner of conversation" (p. 217). This final aspect of creating a positive environment was particularly essential, as online interaction between secondary school learners themselves and between learners and university student volunteers (the school teachers were not added to WhatsApp groups deliberately) could allow secondary school learners to feel comfortable communicating. The fact that there was a little age 
difference between chat members and there were no teachers who could monitor their grammar and spelling helped to build a pleasant environment.

\section{Implementation of the WhatsApp Texting Groups}

After discussing the potential of using WhatsApp with our supervisor and local teachers, we decided to test WhatsApp as a tool to create a safe and accessible space, where local students and the university undergraduate volunteers would communicate with each other on a variety of themes, using only the Kazakh language. Texting activities between university undergraduate students and secondary school Kazakh language learners were conducted in seven groups and lasted four hours (one hour for each class). There were 10 total participants guiding the activities including ourselves and eight volunteer undergraduate students. We wanted to ensure that everyone had access to the resources needed to participate. Fortunately, with this model, the only necessary tool was a smartphone and Internet access, which all the university volunteer students and most secondary school students had. Accordingly, we had to request the list of students from their classroom tutor, develop topics for discussions, and hold preliminary meetings with the university volunteers.

The school provided us with the phone numbers of our participants and we split the secondary school students into seven groups according to their class and teacher (six groups of seventh graders and one group of eighth graders). We assigned group moderators among university student volunteers to each group, ensuring that there was no conflict with regularly scheduled classes. In the end, there were different numbers of volunteers in each chat group, which caused some difficulties, especially in groups where there were only one or two volunteers. The fewer the number of volunteers were in a group, the more problematic and chaotic it was for them to manage the discussion in a lively and engaging manner as well as to answer to every question asked by the children. This number also varied from one group to another, from 9 to 15 children. Nevertheless, we managed to handle this issue because we were taking part in every chat on our own. This is another advantage of holding online discussions. We were able to enter and exit the chats at any time. We tried to monitor the discussions of all chats, paying particular attention to the chats in situations where we felt the volunteers lacked confidence to build interactive communication.

Drawing upon research using the WhatsApp Messenger, our project followed Bouhnik and Deshen's (2014) conclusions that WhatsApp groups are usually used for four purposes: "communicating with students; nurturing the social atmosphere; creating dialogue and encouraging sharing among students; and as a learning platform" (p. 217). Table 2 provides examples of topics and questions that we included for conversational purposes. 


\begin{tabular}{|c|c|c|}
\hline \multicolumn{3}{|c|}{$\begin{array}{l}\text { Table } 2 \\
\text { Examples of topics and questions }\end{array}$} \\
\hline Topics in English and Kazakh & Questions in English & Questions in Kazakh \\
\hline $\begin{array}{l}\text { Leisure time } \\
\text { Бос уақыт }\end{array}$ & $\begin{array}{l}\text { What do you usually do in your } \\
\text { free time? }\end{array}$ & Әдетте бос уақытыңызда не істейсіздер? \\
\hline \multirow[t]{3}{*}{$\begin{array}{l}\text { Movies/cartoons/TV shows } \\
\text { Кино/мультфильм/телехикая }\end{array}$} & $\begin{array}{l}\text { What movies/cartoons/TV shows } \\
\text { do you like watching and why? }\end{array}$ & $\begin{array}{l}\text { Қандай кино/мультфильм/телехикая } \\
\text { көруді ұнатасыздар және неліктен? }\end{array}$ \\
\hline & $\begin{array}{l}\text { What is the latest } \\
\text { movie/cartoon/TV show that you } \\
\text { watched? Did you like it? Why or } \\
\text { why not? }\end{array}$ & $\begin{array}{l}\text { Соңғы көрген } \\
\text { кино/мультфильм/телехикаяңыз қандай? } \\
\text { Ол сізге ұнады ма? Неліктен } \\
\text { ұнады/ұнамады? }\end{array}$ \\
\hline & $\begin{array}{l}\text { Do you like watching } \\
\text { Kazakhstani movies/cartoons/TV } \\
\text { shows? Why or why not? }\end{array}$ & $\begin{array}{l}\text { Қазақстандық } \\
\text { кино/мультфильм/телехикая көруді } \\
\text { ұнатасыздар ма? Неліктен } \\
\text { ұнатасыздар/ұнатпайсыздар? }\end{array}$ \\
\hline \multirow[t]{3}{*}{$\begin{array}{l}\text { Music } \\
\text { Музыка }\end{array}$} & $\begin{array}{l}\text { What music do you like and } \\
\text { why? }\end{array}$ & $\begin{array}{l}\text { Қандай музыка тыңдауды ұнатасыздар } \\
\text { және неліктен? }\end{array}$ \\
\hline & $\begin{array}{l}\text { Who is your favourite singer and } \\
\text { why? }\end{array}$ & Сүйікті әншіңіз кім және неліктен? \\
\hline & $\begin{array}{l}\text { What is your favourite band and } \\
\text { why? }\end{array}$ & $\begin{array}{l}\text { Сүйікті музыкалық тобыңыз қандай } \\
\text { және неліктен? }\end{array}$ \\
\hline \multirow[t]{2}{*}{$\begin{array}{l}\text { Books } \\
\text { Кітаптар }\end{array}$} & $\begin{array}{l}\text { What books do you like reading } \\
\text { and why? }\end{array}$ & $\begin{array}{l}\text { Қандай кітап оқуды ұнатасыздар және } \\
\text { неліктен? }\end{array}$ \\
\hline & $\begin{array}{l}\text { What is the latest book that you } \\
\text { read? Did you enjoy it? Why or } \\
\text { why not? }\end{array}$ & $\begin{array}{l}\text { Соңғы оқыған кітабыңыз қандай? Ол } \\
\text { сіздерге ұнады ма? Неліктен } \\
\text { ұнады/ұнамады? }\end{array}$ \\
\hline \multirow[t]{4}{*}{$\begin{array}{l}\text { Travel } \\
\text { Саяхат }\end{array}$} & $\begin{array}{l}\text { Do you like travelling? Why or } \\
\text { why not? }\end{array}$ & $\begin{array}{l}\text { Саяхаттауды ұнатасыздар ма? Неліктен } \\
\text { ұнатасыздар/ұнатпайсыздар? }\end{array}$ \\
\hline & $\begin{array}{l}\text { How often do you travel? Who } \\
\text { do you travel with? }\end{array}$ & $\begin{array}{l}\text { Қаншалықты жиі саяхаттайсыз? Кіммен } \\
\text { саяхаттайсыз? }\end{array}$ \\
\hline & $\begin{array}{l}\text { What countries/cities have you } \\
\text { visited? }\end{array}$ & $\begin{array}{l}\text { Қандай елдерге/қалаларға саяхаттап } \\
\text { көрдіңіз? }\end{array}$ \\
\hline & $\begin{array}{l}\text { What countries/cities would you } \\
\text { like to visit? Why? }\end{array}$ & $\begin{array}{l}\text { Қандай елдерге/қалаларға } \\
\text { саяхаттағыңыз келеді және неліктен? }\end{array}$ \\
\hline $\begin{array}{l}\text { Sport } \\
\text { Спорт }\end{array}$ & $\begin{array}{l}\text { What is your favourite sport (to } \\
\text { watch and/or play) and why? }\end{array}$ & $\begin{array}{l}\text { Сіздің сүйікті спорт түріңіз қандай } \\
\text { (қарайтын/ойнайтын) және неліктен? }\end{array}$ \\
\hline
\end{tabular}

These topics helped provide a framework for conversation that might feel authentic and engaging for students' language learning.

An important final decision we had to make was whether to insist on or even encourage "proper" written language. After discussion with our faculty supervisor and with each other, we decided to request that the university student volunteers not correct the grammar or spelling of the secondary school students. This decision to allow for students' own construction of sentences and spelling, even when technically incorrect, was established to both encourage greater discussion (without concern for mistakes) and address the fact that most of the local students did not have a keyboard with Kazakh letters installed on their smartphones. 
By encouraging writing in general, we hoped to boost student motivation to use the Kazakh language. Thus, we decided not to discourage the students by pointing out their errors. This process of encouraging communicative practice is commonly found to be useful for teaching and learning a foreign language (CohenMiller, 2010). We found that students learning Kazakh appeared to enjoy the process of talking with their "near peer" without fear of making mistakes: "I liked this lesson/chat. It was really engaging," "Thank you for this lesson! I will be pleased to discuss with you other interesting topics next time," "We really enjoyed chatting with you and I personally learnt a lot from this one hour," "Thanks for not being evaluative and not correcting us, although I know that I made some mistakes," "Thank you for spending this time with us, I really appreciate that," "I will be looking forward to chatting with you again and to meet you tomorrow" (the next day we had face-to-face discussions with these learners, which was the next project activity, but which we have not described here, because it is beyond the scope of this article).

Overall, there were seven conversations on WhatsApp. Two conversations in each seventh grade and one conversation in eighth grade. For teaching L2 in Kazakhstan, the grades are usually divided into two. The total number of students is usually split into two groups and is taught separately by two different teachers. Texting conversations took place in seven total groups and lasted four hours (one hour for each class). In the selected school, there were approximately 24 students split into two groups, creating 12 students in each group conversation. The approximate number of lines of interaction amongst the students and university peers was 180-220 in each group (i.e., in each conversation). The WhatsApp texting groups conducted for this pilot project for school students required thorough preparation, supervision, and effective collaboration not only with the volunteering university students, but also with the Kazakh teachers at the school. The texting group was one of many activities used during the pilot project and was completed by all seventh and eighth graders who initially signed up for the project.

Texting appeared to allow students an opportunity to enjoy conversations, moving from a more passive respondent to actively guiding questions and responses. Within the texting conversations, students were able to build their ideas in a concise way in Kazakh before being "required" to respond. This allowed them a chance to both engage in a synchronous activity and have the opportunity for a delayed response to formulate their written language.

\section{Tangible Results: Using WhatsApp Texting Groups With NPRM}

Based on teachers' and our own reflections, we have understood that the outcomes of the project helped created five tangible results. First, all targeted learners participated in the instructional activities and each learner spoke Kazakh several times during these activities. Second, the project evoked interest in learners and teachers, making everyone eager to participate. Third, we applied NPRM theory by attracting undergraduate student volunteers from the university, which was effective in motivating learners. Fourth, everyone involved expressed willingness to continue the partnership. Lastly, an unexpected outcome of this pilot project was that we helped volunteer undergraduate students and local school teachers build 
capacity while performing the planned activities. For instance, the volunteer undergraduate students built upon their pedagogical skills while delivering discussion and WhatsApp texting group sessions. Initially, volunteer students thought that the conversations would be built around responding learners' questions only. However, we explained to them that it would mostly go the other way round: namely, we would first need to identify the topics that might be interesting for children in this age group, which would involve as many learners as possible in interactive discussions. We also guided the volunteer students so that they would have to ask more open-ended and probing questions, be very cautious in respect to every question and response, in order to ensure they did not ask sensitive questions or offend anyone. After that we discussed the importance of giving timely and encouraging feedback to the learners, enabling them to build a growth mindset. For example, we explained to the university volunteers that praising learners with phrases like "Well done!" and "Good job!" would not be enough. Instead, they would be expected to explain to the learners what exactly was well done/written, and be more specific in motivating them. When we finished all seven WhatsApp activities, we were very pleased to find out from the university volunteers that all the tips that we gave them during our pre-activity meetings helped them build certain pedagogical skills and run the discussions more smoothly, even though none of the volunteers had been studying in the faculty of education.

What surprised us most was that students were very free and confident during the communication sessions. They joked and interacted with the university peers as their equals, and because the interaction was online, students felt less reserved on the whole.

Some students started to lead the discussion by asking us their own questions, sending pictures from their phone cameras, and asking us what we thought about their hobby of taking pictures. We found this particular feature of WhatsApp very helpful_students could share their own photos, screenshots, and videos right from their phones instantly with everyone in the group. Similarly, any information shared in the group could be saved to their phones. This saved a lot of time and helped make the communication dynamic.

\section{Challenges Faced: Using WhatsApp Texting Groups With NPRM}

While there were many positive results, we faced a number of challenges during the implementation. For instance, in such a large group of conversations we were not able to reply to every message. The lack of response from us to some messages left a few students feeling sad and/or left out. Furthermore, as we were heavily reliant on the volunteer students, there was a delay in planning and implementation as it took time to attract volunteers.

Moreover, even though we had also prepared topics in advance for the WhatsApp texting group discussions and provided the volunteers with an approximate plan for holding the discussions, a major challenge was the time-consuming nature of this activity as we had to supervise the discussions, as well as participate in them. 


\section{Reflections and Discussion}

Learning Kazakh in Kazakhstan is recognized as important both to the local population for maintaining national identity and as a key element for employment as jobs increasingly require trilingual abilities (e.g., Kazakh, Russian, English). For the school where we worked, students were identified who had low Kazakh language literacy. Working with them to increase their motivation through digital learning through WhatsApp groups with near peer role models appeared to have positive effects for all those involved. This project has highlighted the potential for connecting local secondary school students with university students using digital technology as a means of facilitating communicative practice for motivating language learning.

For others interested in developing a NPRM texting group to motivate language learning, we have learned through our pilot project that the following aspects should be addressed from the beginning: ensure all students have access to the technology of choice; determine a step-by-step process for responding to students' texts; encourage a free flow of discussion by deemphasizing correction of students' grammatical usage; decide how technological challenges of texting for language in a language such as Kazakh will be addressed considering the lack of specific characters available in that language; provide a step-by-step action plan for implementation for each person involved; and create continuity with activities at the local school extending throughout the school year, paying particular attention to holiday periods (i.e., for our work, this continuity was interrupted by the summer vacation).

As initially planned, our primary aim for this pilot project was to hold activities that might motivate students to learn the Kazakh language. The intended long-term impacts and outcomes consisted of increasing language competence and assisting secondary school students to achieve learning objectives within the curriculum. In order to reach these aims, we used Near Peer Role Modeling to motivate student learning. We established a partnership between the local school and university, in particular with the Kazakh language club. We found that a project with multiple stakeholders and participants is highly time-consuming and requires enormous and detailed preparation. In implementing the WhatsApp texting group, we saw that younger school learners appeared to appreciate both the opportunity to have an alternative to traditional teaching and enjoyed interacting with the university students. Overall, we found positive reactions from the seventh and eighth grade Kazakh language teachers to the instructional activities conducted in collaboration with the university peers. Teachers expressed their hope that this partnership with students and staff from the university would continue, especially considering that a short-term project is unlikely to have lasting effects.

The use of WhatsApp was incredibly valuable for this project, because it allowed learners to be involved in informal communication with their peer models through an application with which they are very familiar. While some projects might encounter issues with student behavior in terms of sending nonsensical messages, as reported in the research by Bouhnik and Deshen (2014), our participants were found to be relatively polite and respectful to each other and with the volunteers throughout the process. 


\section{Suggested Next Steps}

Considering the rapid development of technology, we recommend further exploration of potential technological options, such as sending photos, videos, and/or news links in Kazakh to build engaging contemporaneous discussions. Additionally, potential for incorporating other digital learning strategies or technologies, such as using Telegram (an increasingly common texting app in Kazakhstan) or interactive programs for group discussions (i.e., Adobe Connect), could provide video-conferencing possibilities that could greatly help in organizing communicative sessions. However, as our experience shows, the shortcoming of using videoconferencing is that it requires the use of high-speed Internet, which many students do not have access to even within the capital city.

Future projects on motivation for language learning could examine the evaluation of NPRM theory. For instance, we received positive feedback from the undergraduate student volunteers and local teachers. Future projects could include an evaluation to receive feedback from the local students involved. We believe it is of great importance to find answers to these questions: What did they think of the process? How did they perceive their learning? What did they think was beneficial and what was less beneficial? Additional studies could examine how Near Peer Role Modeling could be applied for attracting 10th, 11th, and 12th grade students to help younger learners tackle their issues in learning Kazakh or serving as "buddies" as role models and "near peers."

While we recognize that a short-term project does not automatically lead to sustained change, the project as outlined can provide a basic overview for others interested in developing collaborations between local schools and universities, complete with potential pitfalls and suggested activities. Additional research will be necessary to determine the long-term effects on motivation for language learning for this particular set of students. We are now planning our next activities for implementation in the coming semester, when the secondary school learners have a new academic school year and the university student volunteers return to their schedule. We hope this project can be the start of a long-term partnership and communication channel and collaboration between the secondary school and university in order to enhance student motivation to learn Kazakh.

\section{References}

Abdyeva, R.S., Nogaybaeva, J.A., Togzhanova, L.K., \& Shynybaeva, A.S. (2015). Kazakh language acquisition and translation from a foreigner's perspective: A case study with English-speaking residents. International Journal of Applied and Fundamental Research, No. 3. Retrieved from www.science-sd.com/462-24896 (13.11.2017).

Arenov, M., \& Kalmykov, S. (1997). The present language situation in Kazakhstan. Russian Social Science Review, 38(3), 56-64.

Belova, O. (2013, November 27). Budusheye Kazakhstana - v kazakhskom yazyke. Retrieved from http://www.kp.kz/society/2978-budushchee- 
Bouhnik, D., \& Deshen, M. (2014). WhatsApp goes to school: Mobile instant messaging between teachers and students. Journal of Information Technology Education: Research, 13, 217-231. Retrieved from http://www.jite.org/documents/Vol13/JITEv13ResearchP217-231Bouhnik0601.pdf

CohenMiller, A. (2008). Stealth language teaching: A preschool foreign language pilot program. Practicing Anthropology, 30(1), 50-53.

CohenMiller, A. (2010). Reflections on a TFLA presentation, One language skill at a time: Exploring the use of FOCAL SKILLS (FS) for K-12 foreign language education. Texas Foreign Language Association Journal.

Dornyei, Z. (2001). Classrooms intended to improve students' pronunciation when teacher Intervention is not enough. Motivational strategies in the language classroom. Cambridge, CUP, 2001, Chapter 1.

Dornyei Z. (2014). Motivation in Second Language Learning. Retrieved from http://www.zoltandornyei.co.uk/uploads/2014-dornyei-cengage.pdf

Fierman, W. (2006). Language and education in post-Soviet Kazakhstan: Kazakh-Medium instruction in urban schools. Russian Review, 65(1), 98-116. doi:10.1111/j.1467-9434.2005.00388.x

Gardner, R. C., \& Maclntyre, P. D. (1991). An instrumental motivation in language study. Studies in Second Language Acquisition, 13(1), 57-72.

Gilmore, A. (2007). Authentic materials and authenticity in foreign language learning. Language Teaching, 40, 97-118. doi:10.1017/S0261444807004144

Kasenova, A. (2016, April 22). Ministr obrazovaniya i nauki o letnih kanikulah, trehyazychii i budushem kazakhskogo yazyka. Retrieved from https://tengrinews.kz/conference/150/

Matuszkiewicz, R. (2010). The language issue in Kazakhstan - Institutionalizing new ethnic relations after independence. Economic and Environmental Studies, 10(2), 211-227.

Murphey T. (1998). Motivating with near peer role models. Trends and transitions. Nanzan University.

NOAA. (2009). Designing education projects (second edition). U.S. Department of Commerce.

Ruddick, M., \& Nadasdy, P. (2013). The influence of near peer role models (NPRMs) in second language. Asian EFL Journal. Professional Teaching Articles. Vol. 65.

Steadham, S. V. (1980). Learning to select a needs assessment strategy. Training \& Development Journal, ASTD, 34(1), 14-15.

The Republic of Kazakhstan. (n.d.).

Retrieved from http://www.akorda.kz/en/republic_of_kazakhstan/kazakhstan

Witte, M. (2014, October 17). Relearning the native tongue: Bringing Kazakh language back to the Steppe. Retrieved from https://www.edgekz.com/relearning-native-tongue-bringing-kazakh-languageback-steppe/

Zhoyamergenkyzy, N. (2013, January 15). Budusheye Kazakhstana - v kazakhskom yazyke. Retrieved from http://www.altyn-orda.kz/budushhee-kazaxstana-v-kazaxskom-yazyke/ 


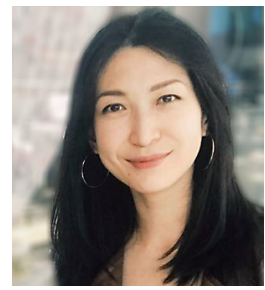

Aliya Gimranova is currently completing a Masters in Leadership in Education at Nazarbayev University. Her research interests include secondary school curriculum development, monitoring of curriculum implementation, teachers' beliefs and practices on curriculum reform, and teacher professional development. While doing her Bachelor's degree, Aliya volunteered to teach English at the university. After graduation, she founded a private education centre that provided English teaching services for children and adults in Astana, Kazakhstan. She now works in a leading education project implemented by Autonomous Education Organisation Nazarbayev Intellectual Schools in collaboration with Cambridge International Examinations.

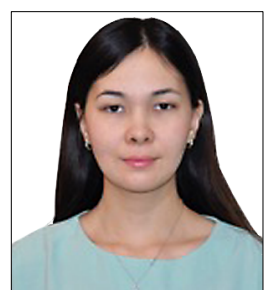

Madina Nurmanova received her bachelor's degree in two foreign languages at Suleyman Demirel University in Kazakhstan in 2008. She started her career as an English teacher in 2008 at a secondary school in Astana. She is currently teaching English at Nazarbayev Intellectual School in Shymkent, Kazakhstan and completing a Master of Science in Educational Leadership at Nazarbayev University in Astana. Madina's research interests are gifted education, technology-assisted teaching, and early childhood education.

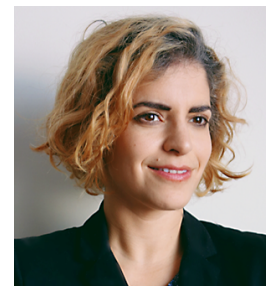

A. S. CohenMiller, PhD, researches topics broadly relating to gender, diversity, and access. CohenMiller specializes in interdisciplinarity and arts-based research. A key component of her work is a focus on collaboration, including mentoring students in conducting research and writing for scholarly publications. Currently, she is engaged in research on issues within academia including recruitment and retention, work/life balance, and educational pedagogy and well-being. CohenMiller is the Founder of The Motherscholar Project, Editor-in-Chief of Dialogue: The Interdisciplinary Journal of Popular Culture and Pedagogy, and Editor of the forthcoming Eurasian Journal of Education. 
Aliya Gimranova, Madina Nurmanova, and A. S. CohenMiller

136 | LEARNing Landscapes | Autumn 2017, Vol. 11 No. 1 